\title{
The role of Pateman's sexual contract in beneficial interests in property
}

Abstract:

While the general law may result in justice between heterosexual intimate partners in particular claims for a beneficial interest in the family home, it does so on its own terms - terms drawn up according to contractarian principles reflecting male sex-right, that subsist even as the world and the institution of marriage (and marriage-like relationships) have changed. This paper uses examples from the case law across four common law jurisdictions to expose the terms on which the contractarian nature of intimate partner trusts permits claims for a distribution of intimate partners' property, and how it excludes. In particular, it identifies the pervasiveness of the sexual contract in subsuming women's expression of individualism to those of her intimate partner, and the implications of this for the derivation of a property interest in the family home. In conclusion it suggests that the transactional norms of property that reflect and uphold the sexual contract should give way to a relational approach in analysing the distribution of intimate partners' property.

The formal equality ushered in by the Married Women's Property Acts ('MWPA') whereby married women might own property in their own right has not been matched by women's broader substantive equality with men (where 'equality' is discussed, eg, by Graycar and Morgan 2004; 2005; 2010; Bonthuys 2013). For many Western women, even as education and paid employment have dramatically improved their economic opportunities, their investment in children, the home, and their relationship continues to come at the cost of genuine economic independence, and their economic and personal security (Summers 2016, preface; Australian Human Rights Commission 2009).

This paper analyses one component of women's access to economic resources: the principles underpinning judge-made law concerning spousal distribution of property in the family home. ${ }^{1}$ It suggests that the law of intimate partner trusts contains a duality that represents the long shadow of the sexual contract, and that the foundation of the general law in this field needs adjustment to deliver equality. Despite the advent of family law statutes, this paper is limited to the operation of judge-made law (general law) which is concerned with principles of property distribution under general law principles. It does not canvass the redistributive effect of family law statutes such as Divorce Reform Act 1969 (UK); Family Law Act 1975 (Cth); Divorce Act 1968 (Canada); Matrimonial Proceedings Act 1963 (NZ). Statutory advances are important but mask the underlying gendered orientation of the common law's approach to determining property interests.

While the general law may result in justice between heterosexual intimate partners in particular claims for a beneficial interest in the family home, it does so on its own terms. The law searches for exchange in the style of a transaction, preferring an expression of intention supported by contribution identifiably related to property acquisition. These are the terms drawn up according to contractarian principles reflecting male sex-right, that subsist even as the world and the institution of marriage have changed. As Carole Pateman observes, "there have been big changes over the last thirty years and patriarchy is obviously not exactly the

\footnotetext{
1 'Intimate relationships' includes married, de facto, and civil unions. 'Spouse' and 'spousal' contemplate all such relationships. This inquiry is limited to heterosexual unions.
} 
same as it was' (Thompson et al 2018, 101). Despite this, Pateman says that 'I haven't changed my mind about any of the major things in the book. And I still think The Sexual Contract has application now, although you have to take into account that society is not quite the same as it used to be' (Thompson et al 2018, 101).

This paper starts with Pateman's premise in The Sexual Contract to analyse what I call here the law of intimate partner trusts. ${ }^{2}$ This is a critique of property law rather than family law. It differs from important critiques of the intimate partner trust through a family law lens (notably Wong 1998; 2005; 2007; 2012) by focusing on the theoretical mechanisms of general law distribution of property. The law of intimate partner trusts offers a case study in the norms of property law that I claim represent the operation of the sexual contract, and necessarily continue to do so. The cases in this area involve claims - generally by women - to a share in the family home arising from a marriage or marriage-like relationship, through an appeal to general law property principles. Regardless of the union's status at law, core gendered features of marriage relations such as systems of financial management and specialisation of household labour are echoed also in de jure intimate relationships (Burgoyne and Sonnenberg 2009; Vogler 2009). The performance of gendered roles indicates the tacit adoption of marriage norms even in de facto unions, and the presence of the sexual contract beyond de jure marriage. This analysis, through Pateman's lens, reveals the limits of property law as a tool of just wealth distribution and highlights how the shift may be made without interfering with the law's own claims to justice.

The hypothesis here is that to succeed in a claim for property in the family home through an appeal to the general law requires women to surmount the sexual contract. As the sexual contract operates as a means of characterising women's work and entitlements within male sex-right, their claims do not comprise the signifiers of a contractual exchange emblematic of the market individual including a demonstrable exercise of free will and contributing quid pro quo. By contrast, where the married woman enters contractual relations through the sexual contract - whether de jure or de facto - her will and her labour are possessed by her partner. It is the very nature of the sexual contract that 'one party... [the husband] has the right to determine how the other party [the wife] will act to fulfil their side of the exchange' (Pateman $1988,58)$. This bargain is at odds with the individualism demanded by the property contract embedded within the law of intimate partner trusts. Consequently it is difficult for women to meet the transactional thresholds embedded within the law of intimate partner trusts.

This paper first establishes the contractual foundations for property in the intimate partner trust cases. In seeking to examine general principles of property law, it takes a broadbrush approach drawing on four common law jurisdictions: England and Wales, Australia, Canada and New Zealand. Selecting cases across four jurisdictions helps to identify the footing of the common law despite the differential doctrinal approaches in each jurisdiction. The second part uses examples from the case law to expose the terms on which the contractarian nature of intimate partner trusts permits some claims for a distribution of spousal property, and how it excludes. In particular, it identifies the pervasiveness of the sexual contract in subsuming women's expression of individualism to those of her husband, and the implications of this for the derivation of a property interest. The final part offers some conclusions about the law's representation of the sexual contract suggesting the alternative derivation of rights from the

\footnotetext{
${ }^{2}$ In England, Wales, and Northern Ireland, called 'common intention trusts'.
} 
relationship itself, seeking to add to contemporary debates about the distribution of property between men and women.

\section{Contractarian Foundations of Property}

There has been significant reform in spousal property across common law jurisdictions in recent decades, notably through introduction of comprehensive family law statutes in the 1970s that permitted judicial redistribution of spousal property in de jure marriages, ${ }^{3}$ and subsequently in relation to de facto relationships in all but England, Wales and Northern Ireland. ${ }^{4}$ Alongside the evolution of family law in the four jurisdictions, the general law has remained available to determine the distribution of property in the family home through declaration of a constructive (and sometimes a resulting ${ }^{5}$ ) trust - albeit to varying extents. In the absence of a statutory scheme, the general law intimate partner trust remains central to determining interests in the family home between de fact partners in England, Wales and Northern Ireland. By contrast, it is less frequently called upon in New Zealand than in the other three jurisdictions as a result of the breadth of application of the Property (Relationships) Act 1976 (NZ). Regardless, it remains good law in all jurisdictions which together afford useful insights into its application.

Unlike statutory family law this 'general law' is property law, concerned not with redistribution based on principles of fairness, ${ }^{6}$ but rather with the parties' original distribution evidenced by the parties' own intentions. The goal of property law thus reflects the goals of contract law in a liberal-market system - upholding the parties' expression of free will as individual citizens - through a contractarian approach to determining the distribution.

Indeed, the parallels between contract and property (relevantly here, in terms of intimate partner trusts) are clear. Like contract law, property law is concerned with exchanges. Following a "contractarian conception of social life, there is contract "all the way down" [and] social life [including in the intimate context] is nothing more than contracts between individuals' (Pateman 1988, 58). Exchange might not be directly invoked in the intimate partner trust but its components, present through the requisite elements of intention and contribution, reflect contract law's agreement - a meeting of the minds - and consideration (see eg Seddon et al 2012, ch 3-4). These prerequisites to property point to bilateralism and mutuality, together indicative of exchange.

Of note and contributing to the duality of the intimate partner trust, the law does not normally recognise contractual exchanges between parties who are emotionally or socially connected and who are therefore found not to hold the requisite intention to create legal relations. ${ }^{7}$ Such exchanges imply the opposite of rationality associated with the utilitarian, materialistic commitment of the man [sic] of the market; rationality that signals and is signalled

\footnotetext{
${ }^{3}$ Notably, Matrimonial Proceedings and Property Act 1970; Family Law Act 1975 (Cth).

${ }^{4}$ For example, first in state jurisdictions in Australia, followed by a national scheme pursuant to the Family Law Amendment (De Facto Financial Matters and Other Measures) Act 2008.

${ }^{5}$ See, eg, discussion in Baumgartner v Baumgartner (1987) 164 CLR 137 per Gaudron J.

${ }^{6}$ See eg Stack v Dowden [2007] 2 AC 432; Muschinski v Dodds (1985) 160 CLR 583; Kerr v Baranow [2011] 1 SCR 269; Gillies v Keogh [1989] 2 NZLR 327.
}

${ }^{7}$ See recently in Ashton v Pratt (No 2) [2012] NSWSC 3 (16 January 2012) which failed on appeal in Ashton v Pratt [2015] NSWCA 12 (16 February 2015). 
by intention and deliberate action. Thus, Silbaugh observes the dichotomy between economic productivity in the workplace and 'housework as an expression of affectionate emotions associated with the family setting' $(2005,338)$ and domestic relations are often characterised by love or altruism (Sandel 1998), ${ }^{8}$ representing community where the law prefers to deal with the rights of an atomistic individual. Private law does not generally concern itself with domestic exchanges.

Unlike purported contractual relations between intimates the law does, however, concern itself with the distribution of spousal property interests - albeit limited to the family home. The early decision of Pettitt $v$ Pettitt laid the foundation for intimate partner trusts across the four jurisdictions because the Court found that such claims lay in property rather than in contract. ${ }^{9}$ However, although some more recent developments appear to cater specifically for the domestic context ${ }^{10}$ (attracting critique: Flood 2011; Probert 2007) general law principles and their market assumptions remain. This has implications for property claims arising from intimate relations, comprehended by the law not in individualistic terms but rather in terms of a sexual contract.

While the jurisdictions outlined here do not share a single doctrinal approach to intimate partner trusts, they share a conceptual foundation grounded in what might be described as market liberalism. As with contract law, integral to the liberal foundation of property is the paramountcy of the individual and the expression of his [sic ${ }^{11}$ will. Individualism explains why courts understand their role as effecting the parties' intended distribution of property, leaving redistribution to the Parliament (Rotherham 2002, 36-39). Individualism is given expression in this area both through the doctrine of separate estates, and through the operation of the law itself.

Unlike some civil law jurisdictions, the common law does not acknowledge community property instead upholding separate estates. ${ }^{12}$ This leaves each spouse to petition independently for their respective beneficial interests to the extent that they claim to differ from the legal title. It might be posited that each spouse is treated by law as an equal individual, capable of representation as a property owner where 'individuals recognise each other as property owners by...exchanging their property' (Pateman 1988, 57). Although spouses hold property as individuals, the intimate partner trust arises as a consequence of the marriage (or marriagelike) relationship and relates specifically to property in the family home-presupposing entry into marital relations howsoever conceived. The facts as contemplated by the law thus simultaneously represent the interests of separate, individual legal persons, and a couple brought together through the sexual contract.

In recognition of separate estates, the law's determination of those estates upholds constructs of free will and differentiated contribution — as laid down in the foundation English

\footnotetext{
${ }^{8}$ See eg Balfour v Balfour [1919] 2 KB 571; Ashton v Pratt [2015] NSWCA 12 (16 February 2015).

${ }^{9}$ Pettitt v Pettitt [1970] AC 777, 796 ('Pettitt').

${ }^{10}$ See eg Stack v Dowden [2007] 2 AC 432; Kerr v Baranow [2011] 1 SCR 269.

${ }^{11}$ In recognition of the gendered individual, this section uses masculine pronouns in reference to market liberal precepts.

${ }^{12}$ Pettitt v Pettitt [1970] AC 777, 810, 817, 824.
} 
decisions of Pettitt ${ }^{13}$ and Gissing $v$ Gissing. ${ }^{14}$ Both cases involved married couples, and the earlier Pettitt was brought under the Married Women's Property Act 1882 (Imp). Pettitt confined the scope of the discretion under the MWPA to finding the parties' separate property. Its purpose was not 'to override existing rights in the property and to dispose of it in whatever manner the judge may think to be just and equitable in the whole circumstances of the case. ${ }^{15}$ The relevant inquiry into the parties' property interests was to be based on general principles of law to be found in the law of trusts, rather than matrimonial or contract law per se. ${ }^{16}$

Mr Pettitt unsuccessfully claimed a beneficial interest in his former matrimonial home, solely owned at law by his wife, based on his in-kind contribution to enhancing its value . As a matter of principle, the Court said that it would find a beneficial interest based on the parties' implied or imputed intention as to the property distribution, ${ }^{17}$ because the "evidence [of intention] is meagre'. ${ }^{18}$ Intention forms the bedrock of a property interest, although in this case the Court could not find the requisite common intention.

Soon afterwards, Gissing affirmed the importance of intention as the foundation of nonlegislative family property law and again, the claimant's contribution to the property acquisition was insufficient to support an intention that she hold a beneficial interest. ${ }^{19}$

The law in England and Wales has developed significantly in the ensuing decades - though not always in a singular direction. Eves $v$ Eves for example saw a woman successfully claim against her de facto partner for a beneficial interest arising from her significant physical contribution to the property's improvement. ${ }^{20} \mathrm{Ms} \mathrm{Grant}^{21}$ and $\mathrm{Ms}$ Oxley ${ }^{22}$ were also successful in claiming a beneficial interest, the Court in each case having identified a clear intention that the applicants were to hold a beneficial interest.

In contrast, in two cases having attracted significant commentary (Mee 2011; Probert 2005; Probert 2001; Wong 2005), Ms Burns ${ }^{23}$ and Ms Rosset ${ }^{24}$ were each unsuccessful in their claims for a beneficial interest because in neither case could the Court find the requisite intention as to property. Notably, in each of these cases the women's actions are readily comprehended by the sexual contract and therefore did not have the characteristic of a market transaction.

The question of how to locate the elusive intention within the domestic context appeared to have been resolved when in 2007 the House of Lords revisited common intention in Stack v

\footnotetext{
${ }^{13}$ [1970] AC 777.

${ }^{14}$ [1971] AC 886 ('Gissing’).

${ }^{15}$ Pettitt $v$ Pettitt [1970] AC 777, 792.

${ }^{16}$ Ibid 822; Gissing v Gissing [1971] AC 886, 902.

${ }^{17}$ Pettitt v Pettitt [1970] AC 777, 799.

${ }^{18}$ Ibid 799.

${ }^{19}$ Gissing v Gissing [1971] AC 886.

${ }^{20}$ Eves v Eves [1975] 1 WLR 1338.

${ }^{21}$ Grant v Edwards [1986] Ch 638.

${ }^{22}$ Oxley v Hiscock [2005] Fam 211.

${ }^{23}$ Burns v Burns [1984] Ch 317.

${ }^{24}$ Lloyds Bank Plc v Rosset [1991] 1 AC 107, 130.
} 
Dowden. ${ }^{25}$ The parties held the legal title jointly, but Ms Dowden claimed a beneficial interest in Mr Stack's estate on the basis of her long-term contributions. The parties' common intention was evinced through examination of matters ranging from their discussions at the time of acquisition, to their financial arrangements, and even to their individual characters and personalities' ${ }^{26}$ although Baroness Hale Baroness Hale was still transactionally focused, searching for the 'subtle factors of intentional bargain'. ${ }^{27}$ Stack was subsequently affirmed and clarified in Jones $v$ Kernott. ${ }^{28}$

The element of intention is found in other jurisdictions too. The leading Australian authorities both examine the parties' intention at close quarters. In Muschinski v Dodds, ${ }^{29}$ the parties held the legal estate jointly. Mr Dodds had not contributed significantly to the purchase price despite a promise to do so, and Ms Muschinski claimed a beneficial interest that reflected her significantly larger capital contribution. The Court found that the parties did intend to hold the property jointly and refused Ms Muschinski's claim. Relevantly, Ms Muschinski had received legal advice, a crucial signifier in this case of her independent will. Baumgartner $v$ Baumgartner $^{30}$ involved a claim by Ms Baumgartner for a one-half interest from her former partner, who held the sole legal title. The Court forensically examined the parties' respective contribution to mortgage payments to ascertain an expression of will-ie the parties' intention - as to the property ownership. Unlike Ms Muschinski, Ms Baumgartner was successful, and the Court declared a trust over a share representing Ms Baumgartner's proportionate financial contribution to the property acquisition. In light of her contribution, it would have been unconscionable to deny her claim.

In contrast to the Australian deployment of unconscionability in the trust cases, Canada adopts an unjust enrichment approach, spelled out in the leading decision of Pettkus v Becker. ${ }^{31}$ Contribution that is not reflected in the legal title will be relevant in determining the fact of enrichment. To establish that the enrichment is unjust, there must be the absence of juristic reason for that enrichment, and a corresponding detriment. One factor in determining this, is the parties' actual intent surrounding their 'joint family venture'. ${ }^{32}$

The New Zealand Court of Appeal observed the approaches in all four jurisdictions to be interrelated, albeit preferring an expectations approach. ${ }^{33}$ On this approach, the parties' expectation of an interest in property represents their will as to property distribution. As is the case in other jurisdictions, the parties' contribution is also relevant, ${ }^{34}$ establishing the investment of self that supports a Lockean justification of property.

\footnotetext{
${ }^{25}$ Stack v Dowden [2007] 2 AC 432 ('Stack').

26 Ibid 459.

${ }^{27}$ Ibid, citing Kevin Gray and Susan Francis Gray, Elements of Land Law (4 ${ }^{\text {th }}$ ed, 2005), 864.

${ }^{28}$ Jones $v$ Kernott [2012] 1 AC 776.

29 (1985) 160 CLR 583 ('Muschinski’).

${ }^{30}$ (1987) 164 CLR 137 ('Baumgartner').

31 [1980] 2 SCR 834.

${ }^{32}$ See discussion in Kerr $v$ Baranow [2011] 1 SCR 269, 319.

33 [1995] 1 NZLR 277, 287.

34 Ibid 285.
} 
In claims for a beneficial interest in property, intention serves the important purpose of evidencing the parties' meeting of minds. It represents the expression of individual will that justifies courts' intervention in otherwise private affairs, to declare the distribution of property. In ascertaining the intention, and to determine the extent of the property interest, courts inquire into contribution. This serves as the quid pro quo evidencing the exchange of individuals that is emblematic of property and of contract.

While the trajectory of the law since Pettitt may appear to indicate refinement in determining spousal property interests, the development of the law has not always been straightforward. Despite courts frequently drawing on the parties' intimate relations to impute an intention, ${ }^{35}$ and to perceive contribution other than capital as sufficient-including, on occasion, contribution in kind ${ }^{36}$ - even in these circumstances the courts' overarching interpretation of the parties' behaviours reflects a transactional understanding of the factual matrix. In circumstances where the court is unable to comprehend that the parties have engaged transactionally, it is far less likely to uphold the property claim. ${ }^{37}$

The paramountcy of transactional exchange, established through intention and contribution, supports a property interest founded upon individualism. Private law enforces transactions entered into between arms-length actors - liberalism's atomistic individuals. Intimate partners' status as individuals is central to their claims to property independent of each other. Yet those property interests derive from their coupledom. Further, and without being expressly acknowledged by the courts, that the subject-matter of the intimate partner trust claims is the family home draws this niche area of property law purely within a domestic purview, demanding examination of the role of the sexual contract.

\section{The Sexual Contract and Common Law Spousal Property Distribution}

On Pateman's account (1988), the social contract theorises how all people are brought within civil society - yet the social contract adopts the structures of patriarchy to exclude women's full participation. She posits an unacknowledged bargain implicit within social contract theory: the sexual contract. Women too enter into the contractual relations that define society, but they only enter civil society via their relations with men. Women are ostensibly included within society yet are simultaneously consigned to an inferior status, occupying the interior world of the private sphere, through the operation of the very structures that include them (Arendt 1998).

Pateman's argument provides insight into the operation of the law of intimate partner trusts. On the one hand, in response to a claim by one spouse, this law applies equally to men and women as individual rights-holders to establish the distribution of their individual property in the family home. It reflects the so-called 'general law' of property, rather than family law statutes which instead redistribute spousal property upon separation. In the same way as the law applies to the arm's-length transactions of the market, so too are husbands and wives brought within the purview of the law, required to demonstrate intention as to an underlying

\footnotetext{
${ }^{35}$ Notably in the Canadian cases, eg, Kerr v Baranow [2011] 1 SCR 269. See also Baumgartner v Baumgartner (1987) 164 CLR 137; Jones v Kernott [2010] 1 WLR 2401.

${ }^{36} \mathrm{Eg}$, Seguin v Vanasse, reported in Kerr v Baranow [2011] 1 SCR 269.

${ }^{37}$ See, eg, Lloyds Bank Plc v Rosset [1991] 1 AC 107; Burns v Burns [1984] Ch 317; Cossey v Bach [1992] 3

NZLR 612; Murdoch v Murdoch [1975] 1 SCR 423.
} 
property interest in the family home, and a contribution sufficient to support the claim to property.

On the other hand, the motives (intention) and value (contribution) ascribed to spousal parties in establishing a right to property generally recognise and reward the individualism of the market as an implicitly public undertaking while ignoring or discounting that which is 'personal' or within the intimate realm (Olsen 1983). Individualism is established in property claims through the lens of transactional exchange between equals, reflecting the tenets of classical contract (Macneil 1974). At the same time, I suggest that the personal includes those activities and behaviours that are implicit within the sexual contract. Although the law is prepared to entertain a claim for property arising from an intimate relationship and while women are admitted into the court as equal citizens to prosecute such a claim, the law's inherently patriarchal norms either preclude women from success, or reward only those claims in which women's intimate relationships reflect transactional norms. In this latter case, I suggest that where women's behaviour within intimate relations can be construed as something over and above that which is contemplated by the exchange in the sexual contract, only then will courts recognise it as sufficient to evidence distribution of property. If women's domestic behaviour can be accounted for by the sexual contract, then it will not support a property interest.

Intimate partner claims for a beneficial interest occur within the common law by virtue of the 'shared home', but remain secondary, private, and relational, in a way that tends to exclude them from the operation of the law. Such claims find acceptance within property law only where they can be measured in terms of dominant transactional norms beyond the sexual contract. Further, while the contractual foundations of property rely on transactional exchange, the sexual contract obviates such exchange, as the exchange is one of obedience for protection (Pateman 1988, 7). Once married (or having entered into marriage-like relations) the woman's labour and her will is subsumed by the sexual contract. Consequently, financial and nonfinancial contributions alike, occurring within the household, do not meet the transactional general law standard for becoming a propertied individual. This is reflected in the law of intimate partner trusts.

On a general analysis, women's capacity to exchange as individuals has been informed by the gender norms at the heart of marriage, which traditionally deprived women of full legal personhood and of property (Shanley 2008, 295). These gendered constraints formed the unalterable foundation of the marriage 'contract', where free will existed - if it existed at all — through the decision of whom to marry (Galloway 2015). 'Choice' to enter marriage has historically been institutionally circumscribed including by social expectations and women's employment opportunities. As Pateman points out, 'personal circumstances are structured by public factors' $(1989,131)$. Thus, the marriage 'contract' itself, in negotiating terms, (Elshtain 1982; Pateman 1988) constituted a 'not fully articulated act of will' (Okin 1989, 123) and with the lack of expression of the terms of the arrangement is the absence of exchange within the marriage. Despite the MWPA and second-wave feminism, the gendered foundation of marriage remains, as traditional asymmetries in marriage have survived women's 'full legal enfranchisement' (Krouse 1982, 150). Contemporary studies confirm that this remains the case (Yodanis and Lauer 2014).

Drawing on Pateman's argument, beyond simply describing marriage as a gendered construct resulting in gendered property distribution, marriage and its proxy of cohabiting partners, represents the sexual contract; the means by which women are inducted into civil society yet denied the status of individual (Pateman 1988, 178). As with the theorisation of a 
contractual foundation for civil society the intimate partner trust adopts contractual principles to justify spousal property, resting on an exchange evidenced by intention to distribute property and supported by contribution to mark the quid pro quo.

Following from this, the law provides an individualistic contractual account of spousal relations to justify a property interest. Simultaneously however, it deploys those same norms frequently to deny wives' individualism through default characterisation of their intentions, and their contributions, as insufficiently contractual to constitute property. Instead the law by default interprets women's intentions and contributions as indicia of the sexual contract displaced as Pateman observes, onto the marriage contract $(1988,175)$.

As Pateman points out, 'husband and wife cease to be self-subsistent individuals. They are members of an association so closely unified that they become one person' $(1988,174)$. Within public discourse, 'family' remains a single economic unit, 'represented in public by the husband the "one person" created by the marriage contract' (Pateman 1988, 176; Fineman 1995) - circumstances not conducive to the construct of market exchange. Yet the ostensibly unitary family is simultaneously populated by individuals (Estin 2005). This is borne out by the intimate partner trust that distributes property based on each partner's expression of individualism as recognised by law.

The tension between unitary marriage and individualism exists for women but not for men. Women may appear to be individuals, but as Pateman argues the individual is in fact a gendered subject or a 'patriarchal category' $(1988,167)$. Therefore, a wife's individualism is subsumed to that of her husband so that '...freedom becomes obedience, and in exchange, protection is provided' (Pateman 1988, 7). While individuals (men) exchange as an expression of free will, the category of wife might exchange emotionally or 'virtuously', but not according to 'rational' market imperatives (Mayes 2005; Fineman 1995) and not as an expression of freedom. In contrast with the characterisation of exchange transactions as evidencing an expression of free will as to property distribution, ${ }^{38}$ domestic exchanges, especially those undertaken by women, are said to be founded on emotions such as love, altruism, and nurture (Walzer 1983; Sandel 1998; Silbaugh 2005). Law, as an expression of liberalism including the atomistic individual, thus contrasts rational self-interestedness which might support property, with caring altruism which is unlikely to do so. The contrast reflects the dichotomy of the (market) transaction and (domestic) relations (Olsen 1983). This dichotomy is especially apparent in the treatment of non-financial contribution in the case law. ${ }^{39}$ Compounding the issue for women claimants, examining individual claims without broader structural context is more likely to mask the effects of the sexual contract. ${ }^{40}$

In the market, work is economic and is exchanged for money. By contrast courts frequently construe labour in the home as part of a necessarily non-economic, altruistic exchange, (Moody-Adams 1997) evidenced by their reference in the trust cases to 'ordinary

\footnotetext{
${ }^{38}$ See, eg, discussion in Baumgartner v Baumgartner (1987) 164 CLR 137, 155.

${ }^{39}$ For the most egregious example, see Murdoch v Murdoch [1975] 1 SCR 423, 443.

${ }^{40}$ By way of case study, the Court ignored the stigma attached to unmarried cohabitants in Baumgartner $v$

Baumgartner (1987) 164 CLR 137.
} 
domestic duties' (Silbaugh 2005; Kessler 2005, 373) (11 $^{4}$ that attract no legal consequences ${ }^{42}$ under the general law, despite the law attributing value to 'domestic' labour in other contexts (Graycar 1992). The distinction illustrates the doctrine of separate spheres in practice: the requirement that women comprise the private sphere that is 'both part and not part of civil society' (Pateman 1988, 180). Men's patriarchal right is dependent upon women's subjection in civil society, achieved through women's separation into the private, through the sexual contract (Pateman 1988). I suggest that this is embedded in, and therefore upheld, through the law's treatment of women's claims to property in the family home.

Within the contractarian mould of property, establishing that intimate partners engage in exchange is necessary to justify an interest. In a property transaction at law, it is the transferee's investment in, or payment of the price for, property that supports their interest. In a direct exchange in the form of a quid pro quo, both the intention as to distribution and the contribution to uphold the interest work together to link the exchange to the acquisition of property rather than to some other purpose.

Pateman characterises the marriage contract as a 'permanent exchange...of obedience for protection' $(1988,58)$. The daily contribution of the parties is therefore determined by one party - the party providing protection. On her analysis, exchange has already occurred at the point of establishing the parties' relations, and no longer registers as contractual while the relationship subsists. In contrast to a discrete transaction, a spousal division of labour does not presuppose exchange through quid pro quo, one task for another.

The courts' characterisation of spousal contributions as meaningful in property terms is generally obscured by their imperative of locating a discrete transaction, and in particular by the courts' (acknowledged) artificial search for intention. ${ }^{43}$ As exchange, a couple's domestic activities transgress the individualistic assumptions of rational utility-maximisation implicit in contract and property law. Instead, they ' [take] place in the context of relations more extensive than the exchange itself...' (Macneil 1986, 577). MacNeil's view of exchanges on a spectrum from 'pure' transaction to relations - the most pure of which is 'a marriage of the more traditional kind' (Macneil 1974, 720) — sees contract law privileging the hallmarks of an identifiably discrete transaction while ignoring the reality of exchange relations (Macneil 1974).

Just as the underpinning liberal market ideals of contract law might be reconceptualised as relational, I suggest that so too can the indicia of (transactional) property law be understood in relational terms. To do so, however, requires comprehending the ongoing and relational nature of a couple's exchange beyond the point of entry into the sexual contract. Assuming the sexual contract means comprehending domestic activities as already answered for the original exchange of obedience for protection. Women's 'contribution' is therefore not necessarily

\footnotetext{
${ }^{41}$ See also Pettitt v Pettitt [1970] AC 777, 826; Lankow v Rose [1995] 1 NZLR 277, 285.

${ }^{42}$ The context for this is the absence of intention to create legal relations through exchange occurring in the intimate context. See eg Balfour v Balfour [1919] 2 KB 571, affirmed in Ashton v Pratt (No 2) [2012] NSWSC 3 (16 January 2012). The latter was upheld in Ashton v Pratt [2015] NSWCA 12 (16 February 2015) though without citing Balfour.

${ }^{43}$ See eg Pettitt $v$ Pettitt [1970] AC 777, 799.
} 
relevant in ascertaining a property interest because it occurs pursuant to another contract: the sexual contract.

The law will, however, uphold claims backed up by an exchange having the appearance of discrete transaction - and these are more frequently undertaken by men who tend to be the party better equipped, through structural advantages, to do so. ${ }^{44}$ The discrete transaction tends to be discernible from outside the 'black box' (Pahl 1989, 3-4) of the marriage, evidenced as it is by actions such as payments to the mortgagee. Within the black box however, 'the transfer of resources between earners and spenders has been rendered invisible' (Pahl 1989, 3-4) as a consequence, I suggest, of the sexual contract. Regardless of the exchange of resources that might occur within marriage, a claim will fail the benchmark of transaction where the exchange is understood to comprise the labour and other contribution subsumed within the sexual contract. Conversely, contribution will be sufficient to support a claim to property only where it can be understood in transactional terms as an exchange ie an exchange that is accounted for other than by the sexual contract. This argument is illustrated in the following case studies of the courts' treatment of both financial and non-financial contributions: where the parties' conduct can be explained by the sexual contract, the court is less likely to find a property interest but where the conduct exhibits the hallmarks of an arms-length transaction it is more likely to support a property interest.

\section{Financial contributions}

The case law canvasses three principal forms of financial contribution: capital payments, noncapital expenditure (on the property directly), and what I describe here as household expenditure-payments relating to the running of the family. Capital contributions to the acquisition of the property that are not reflected in the parties' legal interest, would generally be dealt with under the law of resulting trusts. ${ }^{45}$ Such payments are most easily comprehended as transactional: a quid pro quo for an interest in property.

Of note, however, Ms Muschinski was unable to derive a beneficial property interest through her capital contribution of almost the entire purchase price. ${ }^{46}$ Instead, the Court found that Mr Dodds' promise to contribute capital was enough to secure his legal interest. Likewise, Ms Cummins failed in her bid to protect her 75 per cent capital contribution to the acquisition of the original family home. ${ }^{47}$ In this case, invoking the absence of exchange indicative of the sexual contract, the High Court found that in a marriage, it was not material who paid for what.

In contrast to capital contribution, in the domestic context in particular, non-capital financial contributions are ad hoc or dispersed over time. They lose the obvious transactional quality of the capital payment, resulting frequently in more 'guesswork and intuitive

\footnotetext{
${ }^{44}$ Although note, eg, Stack v Dowden [2007] 2 AC 432; Lankow v Rose [1995] 1 NZLR 277; Pettkus v Becker

[1980] 2 SCR 834, where in each case the woman claimant demonstrated sufficiently transactional behaviour to succeed in her claim.

${ }^{45}$ See eg Baumgartner v Baumgartner (1987) 164 CLR 137, 155.

${ }^{46}$ Muschinski v Dodds (1985) 160 CLR 583. Though not a property interest, the Court did, however, grant a charge over Mr Dodd's half legal interest to protect Ms Muschinski's disproportionate capital contribution.

${ }^{47}$ Trustees of the Property of Cummins v Cummins (2006) 227 CLR 278.
} 
judgement' (Macneil 1981, 1043) informing each party's contribution than the rational calculation that occurs in a directly reciprocal exchange.

Non-capital financial contributions were central to deliberations in Baumgartner where Mr Baumgartner held the sole legal title. ${ }^{48}$ The Court in Baumgartner weighed the contributions to a joint account, to determine the parties' respective interests. Mr Baumgartner had used the proceeds of sale of his solely-owned unit to pay the deposit for his purchase of real property as the couple's home but used the parties' pooled funds to pay off the mortgage. Ms Baumgartner claimed a beneficial interest in that property on the basis of having contributed her weekly pay packet to that joint account for the purpose of paying the mortgage repayments.

The Court declared that Mr Baumgartner held the property on trust for the couple jointly, reflecting their proportionate contribution to the acquisition, subject to a charge in $\mathrm{Mr}$ Baumgartner's favour covering his initial capital contribution. Despite Ms Baumgartner's lack of capital contribution to the property purchase, and the lack of specific application of the pooled funds to pay off the mortgage, the Court found sufficient intention that the parties' joint funds would be used to purchase the land. The Court thus attributed to the pooled money a purpose of land acquisition even though they were in fact, under Mr Baumgartner's sole control, expended on diverse household purchases. The Court found that it would be unconscionable for only one contributor to the fund (Mr Baumgartner) to assert ownership of the asset purchased.

Of note in this case Mr Baumgartner controlled all the parties' finances, and in that role, demanded Ms Baumgartner's wages and controlled all spending. ${ }^{49}$ In light of the traceability of her funds to the property, the finding of unconscionability resonates. The Court needed, however, to circumvent Mr Baumgartner's male sex-right to protect Ms Baumgartner's interest, using the device of intention as to property to do so. In this case there was sufficient evidence concerning the property acquisition to support the element of intention, and sufficient nexus between the financial contribution and the property acquisition to suggest an exchange. Ms Baumgartner had argued that Mr Baumgartner had promised that they would marry and that in reliance on this promise, she had contributed to the pooled resources. The Court saw the marriage promise as irrelevant: Ms Baumgartner had to raise her claim beyond the sexual contract, and Mr Baumgartner's claims of entitlement to her funds to defeat his assertion of property.

In Jones $v$ Kernott the parties had separated some 12 years before the claim. During that time, Ms Jones alone had borne the mortgage repayments of a jointly-owned house. The English Court recognised 'the practical difficulty...of taking any...account [of financial contributions], perhaps after 20 years or more of the ups and downs of living together as an unmarried couple. ${ }^{50}$ The financial contributions were considered unspecific relative to the property acquisition, as is characteristic of non-capital contribution in intimate relations. There was therefore little to indicate exchange at the outset as a marker of a discrete transaction and Ms Jones had work to do to establish that her years of repaying the mortgage might sound in a property interest in the face of her former partner's denial. She was successful, convincing the Court that the exchange was sufficiently transactional to warrant a beneficial interest. Of note,

\footnotetext{
${ }^{48}$ Baumgartner v Baumgartner (1987) 164 CLR 137.

${ }^{49}$ As recited in evidence. See Baumgartner v Baumgartner (1985) 2 NSWLR 406, 436, 437.

${ }^{50}$ Jones v Kernott [2012] 1 AC 776, 785.
} 
the parties had separated some time before the action, and came before the court as individuals. While Ms Jones had herself contributed to the mortgage, in these facts this reflects the parties' independence. Despite their long-term relationship and the domestic genesis of the property claim, the exchange of now-independent parties is perhaps more likely to become visible, perceived outside the confines of the sexual contract. The findings in Jones v Kernott thus continue to support the underpinning transactional norms of property law, and as Sloan has observed, its subsequent application has not appeared to liberalise the courts' approach (Sloan 2015).

It is notable also that Jones $v$ Kernott adopted the reasoning in Stack, taking account of diverse and ostensibly relational aspects of the parties' long-term exchange. ${ }^{51}$ Although Baroness Hale's indicia in Stack represent a significant advance towards the reality of exchange in intimate relations, the circumstances of neither of these cases evidences a relational analysis because, in each case, I suggest that the women claimants' actions were capable of being understood independently of the sexual contract. In Stack, for example, it was the highly unusual separation of the parties' income and expenditure that evidenced an intention that they hold differential beneficial interests.

The Court's reading of the parties' behaviour in Stack could be interpreted in two ways. On one hand, the style of money management is akin to a transaction, namely a deal that Ms Dowden pay expenses and own the property despite the joint interests in law. Alternatively, Ms Dowden's payments, like those of Ms Baumgartner, may have been sufficiently discrete contributions measurable in terms of property itself. In either case, while the Court acknowledged payments sufficient to support a beneficial interest, Ms Dowden was successful because her mode of contribution could be interpreted as transaction. In keeping their accounts 'rigidly separate' ${ }^{52}$ the parties themselves were behaving as market individuals.

While property-related financial contributions may be somewhat difficult to link to the acquisition, the most difficult type of financial contribution for courts to reconcile with a property interest is that of payments to support the household. Household payments are the most removed temporally, and in terms of intention, from an exchange aligned with property acquisition. Despite the calculable dollar value over time of household payments, they are difficult to comprehend as a quid pro quo for property.

The guesswork of household financial management and its effect on property claims shows in the facts of many cases - for example, where a spouse loses their job, ${ }^{53}$ has a child, ${ }^{54}$ misses out on an expected divorce settlement ${ }^{55}$ or has an extra-marital affair ${ }^{56}$ the parties' contributions to the household will inevitably change. Household financial contribution over time is therefore rarely measurable specifically in relation to the property transaction at the time of purchase. Because payments are easily interpreted as being for some purpose other than

\footnotetext{
51 Ibid 794.

52 Stack v Dowden 465.

${ }^{53}$ Grant v Edwards [1986] Ch 638.

${ }^{54}$ Fowler v Barron [2008] EWCA Civ 377.

${ }^{55}$ Muschinski v Dodds (1985) 160 CLR 583.

${ }^{56}$ Gissing v Gissing [1971] AC 886.
} 
property, courts can disregard them. ${ }^{57}$ This is particularly so where household expenses fall within the purview of the wife's responsibilities; an adjunct to the sexual contract.

In Fowler $v$ Barron for example the trial judge had found that the parties, who held the title to their home in law as joint tenants, did not hold equal beneficial interests. ${ }^{58}$ The judge relied on the fact that Mr Barron had provided the deposit, paid the mortgage, paid the balance purchase price from the proceeds of sale of his solely owned flat, and paid the taxes and outgoings. In contrast, Ms Fowler spent her income 'on herself and her children'. ${ }^{59} \mathrm{Mr}$ Barron's financial contributions were discernibly transactional in property terms while Ms Fowler's contribution fell clearly within her wifely responsibilities.

The decision was overturned on appeal. Following Stack v Dowden (decided after the trial judgment was handed down) Arden LJ observed that 'it was not so much the unequal contributions to the purchase of the house that mattered, rather the inferences as to the shared intention to be gleaned from the evidence overall. ${ }^{60}$ The intention to hold beneficially equally would by default follow the joint interests in law, unless Mr Barron could present sufficient evidence to displace this presumption. In the absence of some common intention about a differential beneficial interest, expressed or inferred, 'it should make no difference to their interests in the property which party paid for what expense. ${ }^{, 61}$

This finding avoids having to characterise the financial contribution according to arm'slength transactional norms. Instead, it focuses on intention represented by the legal interest, offering a shield against Mr Barron's assertion rather than a clear source of contribution to support a claim by Ms Fowler. It does not therefore grapple with the dismissal of Ms Fowler's expenditure, and how her contributions to the household might be dealt with in a positive sense. In light of Baroness Hale's list of factors relevant to considering financial contribution, ${ }^{62}$ it is feasible that Ms Fowler's household contributions would have been acknowledged — though it is impossible to say what weight they would carry. Of interest though, is that in finding that the equitable interest follows the law, Fowler leaves unstated the absence of exchange value in Ms Fowler's family-focused expenditure arising from the sexual contract and thus unable to be reconciled within the individualist norms of property law. A positive finding that such expenditure, undertaken over time and without expression in property terms, might found a property interest would represent a significant — relational — shift in the transactional nature of the general law.

Unlike mortgage payments whose object is the property itself, the question facing the court in a claim based upon other types of financial contribution is whether meeting these expenses demonstrates sufficiently direct reciprocity between the parties in terms of property. The nature of these financial contributions might be meeting household expenses, ${ }^{63}$ or the cost

${ }^{57}$ See eg Mr Lankow's failed attempt to argue that his partner had received ample benefit from her contributions, including a home, cars, holidays and a comfortable lifestyle: Lankow v Rose [1995] 1 NZLR 277, 285.

58 [2008] EWCA Civ 377 ('Fowler').

${ }^{59}$ Ibid [7].

${ }^{60}$ Ibid [47].

${ }^{61}$ Ibid [42].

62 Stack v Dowden [2007] 2 AC 432, 459.

${ }^{63}$ Fowler v Barron [2008] EWCA Civ 377. 
of raising the children. ${ }^{64}$ On a transactional analysis, there is no ostensible expectation of a quid pro quo of property in these circumstances, and courts' approach to such contributions has been variable.

Part of the reason for the variability in treatment of these expenses, notably those associated with children, is that they tend to be covered by family law statutes. Expenses may be recoverable, or one parent might have a right to share costs under redistributive statutory provisions. These expenses are thus categorised as having family or children as their object, rather than property. To the extent that they fall within the realm of wives' obligations under the sexual contract, the (family) law provides redress outside the contractarian framework.

While this approach is important, it fails to answer the problems with property. It is of no assistance to a claimant that they may be compensated under a different regulatory framework, where there is no accounting for the opportunity cost of child support vis-à-vis property acquisition. Regardless of whether distribution of household income is dealt with via family law, such reckoning does not address the nature of the parties' overall relative financial contributions within the household and the distributive effect of this in terms of property. Thus, family law deals with exchanges within the sexual contract and contractarian property law upholds transactional exchange that is inherently outside the sexual contract.

\section{Contribution to domestic life}

In addition to household financial contribution, the cases deal with labour expended on what was described in Kerr $v$ Baranow as the 'joint family venture'. ${ }^{65}$ Similar market metaphors were applied in Muschinski ("a "joint venture", a "partnership"). ${ }^{66}$ The joint venture analogies recognise the inevitably materially intertwined lives of the parties not just financially, but also through labour.

Generally however, for intimate partner trusts there is a requirement that to 'count' as contribution, labour must be beyond the 'sort of things which a wife does for the benefit of the family' such as 'clean[ing] the walls or work[ing] in the garden or help[ing] her husband with the painting and decorating'. ${ }^{67}$ Day-to-day domestic labour is therefore not associated with a beneficial interest, falling as it does outside the requisite transactional framework. In particular, it fails to be sufficiently measurable and specific in terms of a transaction concerning property. Silbaugh, for example, observes that the way in which housework is characterised as private and 'emotional' 'den[ies] material security to the performers of domestic labour'. (Silbaugh $2005,357)$ Such labour is owned by the husband by virtue of the sexual contract and is therefore not available as exchange value for property.

Additionally, unlike the classic market transaction, domestic contribution is not inherently transferable but is 'unlimited and unique' to the couple (Silbaugh 2005, 357). For example, the housewife's investment in her domestic skills is specific to the needs and wants of her spouse. As Pateman points out, 'what being a woman (wife) means is to provide certain services for and at the command of a man (husband)' $(1988,128)$ and what those services are, depend on the husband's needs $(1988,129)$. Although an economic or a legal analysis might

\footnotetext{
${ }^{64}$ Fowler v Barron [2008] EWCA Civ 377.

65 [2011] 1 SCR 269, 304.

${ }^{66}$ Muschinski v Dodds (1985) 160 CLR 583, 611.

${ }^{67}$ Pettitt v Pettitt [1970] AC 777, 796, citing Button v Button [1968] 1 WLR 457, 462.
} 
find alternative services in the market, this fails to appreciate the plural meanings of a single activity (Silbaugh 2005, 349). Domestic labour might thus be simultaneously economic and emotional. Yet although domestic labour is measurable in an economic sense, in the intimate partner trust cases the courts tend to choose not to do so, perceiving it as altruistic and beyond the law. In this way, domestic labour is accounted for not as part of a property transaction, but as part of the sexual contract.

This tendency is illustrated in the somewhat older and notorious Canadian decision of Murdoch v Murdoch, where Ms Murdoch worked on Mr Murdoch's three ranches, including:

Haying, raking, swathing, moving [sic], driving trucks and tractors and teams, quietening horses, taking cattle back and forth to the reserve, dehorning, vaccinating, branding, anything that was to be done. I worked outside with him, just as a man would, anything that was to be done. ${ }^{68}$

Mr Murdoch was absent from the ranches for five months of every year, during which time Ms Murdoch performed these tasks on her own. Mr Murdoch described her work as that of 'an ordinary rancher's wife'. ${ }^{69}$ The majority did not consider her labour relevant to her claim for joint ownership of the ranches. In searching for evidence of an intention that she hold a beneficial interest, the majority held that her contribution was that of a ranch wife, rather than contribution sounding in a beneficial interest. ${ }^{70}$

The decision to categorise Ms Murdoch's contribution as that of 'a ranch wife' illustrates the way in which the courts have traditionally used the public/private divide to include or exclude labour from calculations of a beneficial interest. Relegating this labour to the domestic realm, the Court in Murdoch reinforced the transactional norms required to justify a beneficial interest. Doing so upheld such labour within the terms of the sexual contract.

Ms Murdoch aside, there are examples where the nature of the applicants' contribution is so extraordinary as to represent effort not normally contemplated within the sexual contract and therefore is more likely to be considered as a contribution sufficient to support a beneficial interest in property. Therefore Ms Becker's extraordinary contribution to the couple's honey business was central to the declaration of her beneficial interest in Mr Pettkus' sole legal title. ${ }^{71}$ The words of the judgment highlight how the Court perceived Ms Becker's contribution as beyond 'mere' wifely duties. Lugging heavy beehives, almost her own weight, for the couple's beekeeping business, working with Mr Pettkus 'continuously, unremittingly and sedulously in the joint effort', ${ }^{72}$ the Court could only comprehend such effort beyond the sexual contract. She would only behave this way if she expectated a quid pro quo - that is, her contribution necessarily supported an intention to hold a beneficial interest in the property.

The Canadian unjust enrichment approach does provide greater possibility for women to demonstrate a quid pro quo through their labour, ${ }^{73}$ implying that women's labour might be their own, freely exchangeable for property. Of note, however, the context for making the argument is that of a marriage or marriage-like relationship (and the Court in Pettkus v Becker

\footnotetext{
${ }^{68}$ Murdoch v Murdoch [1975] 1 SCR 423, 443.

${ }^{69}$ Ibid 444.

${ }^{70}$ Ibid $437-8$.

${ }^{71}$ Pettkus v Becker [1980] 2 SCR 834.

72 Ibid 853.

${ }^{73}$ See, eg, Seguin v Vanasse, reported in Kerr v Baranow [2011] 1 SCR 269.
} 
found that there was no material difference between the two). ${ }^{74}$ The claimant must act to her detriment to avail herself of the claim, and to illustrate the point, the Court observed Ms Becker's significant effort. A detriment therefore appears to go beyond the labour normally expended within the marriage. The analysis therefore remains transactional in the mould of individuals. Presumably, Ms Becker through her actions had stepped outside the sexual contract and in doing so became visible as an individual in an exchange of labour for property.

Similarly, Ms Lankow made an extraordinary contribution to Mr Rose's property investments that resulted in a significant increase in the value of his holdings. ${ }^{75}$ She used her skill as a legal secretary 'out of office hours, at lunchtime, in the evening and at weekends, ${ }^{76}$ to improve Mr Rose's affairs. The extent of her contribution played an important role in the Court upholding her beneficial interest in his solely owned property.

This overview illustrates the undercurrent of the sexual contract within judicial reasoning in the intimate partner trust cases. Certainly, the law has advanced since the notorious decisions in Burns ${ }^{77}$ and Murdoch. ${ }^{78}$ Hayward (2012), for example, describes the 'familialisation' of property law - a movement in which the general law has evolved informed by the jurisprudence of family law and with it, the norms of domestic life. With this evolution, courts now accept a far broader range of contributions than were contemplated in the early cases. But this alone is not enough. This approach relies on discretion as a means of 'ameliorat[ing] the implied trusts framework' (Hayward 2013,33) and therefore fails to grapple with the structural inequity wrought by the sexual contract and continues to uphold the transactional features of property law that ignore the relational context of exchange in furtherance of the couple's shared purpose.

\section{Some Conclusions}

The majority of the intimate partner trust cases involve claims by women for a beneficial interest over a legal estate held by their male partners. Of these women-wives - those whose husbands held the entire legal estate claimed on the basis that the home was to be shared. ${ }^{79}$ Others sought to claw back an interest representing their own disproportionate financial contribution. In all cases, the possibility of a lesser, discretionary, and fragile entitlement to a beneficial interest in property rested upon their proving an exchange within their marriage or marriage-like relationship in the face of their husbands' denial not only of their interest, but of the women's contribution to the parties' mutual economic wellbeing. ${ }^{80}$

\footnotetext{
${ }^{74}$ Pettkus v Becker [1980] 2 SCR 834, 850.

${ }^{75}$ Lankow v Rose [1995] 1 NZLR 277.

76 Ibid 284.

${ }^{77}$ Burns v Burns [1984] Ch 317.

${ }^{78}$ Murdoch v Murdoch [1975] 1 SCR 423. Although the 2006 Australian High Court decision in Cummins is considered somewhat regressive: Trustees of the Property of Cummins v Cummins (2006) 227 CLR 278; Sarmas 2012.

${ }^{79}$ Baumgartner v Baumgartner (1987) 164 CLR 137; Pettkus v Becker; Lloyd's Bank v Rosset; Burns v Burns; Eves $v$ Eves etc.

${ }^{80}$ Notably, in Baumgartner v Baumgartner (1987) 164 CLR 137, Pettkus v Becker [1980] 2 SCR 834 and Lankow v Rose [1995] 1 NZLR 277.
} 
Pateman's theorisation of a sexual contract explains not only these men's insistence on their entitlement to property in the home, but also the law that resolves the parties' distribution. The law provides a contractarian solution to spousal property distribution requiring claimants to establish themselves as free individuals in an exchange transaction, evincing the intention indicative of free will and an investment of self - a contribution - that upholds their right. In doing so, the law demands the liberal ideal of consent and contribution in a context where women's freedom to make the claim is predicated on their subordination to the men from whom they claim (Thompson et al 2018). The contractarian property distribution is an extension of the sexual contract, operating through marriage (or marriage-like relations) as its proxy. Pateman observes that '[c]onjugal relations are part of a sexual division of labour and structure of subordination that extends from the private home to the public arena of the capitalist market' $(1988,115)$. In turn, the intimate partner trust is the superimposition of the capitalist market and its claims of equality and consent into conjugal relations to establish spousal property distribution.

This is not to deny that women claimants might succeed in convincing courts of a transactional exchange; or rather, courts will be prepared to interpret the facts that way. Success in the application of the law does not, however, demonstrate that women are equal individuals before the law. Instead, such cases illustrate that for women to succeed in a general law property claim against their spouse they must provide a convincing account of their relations beyond the sexual contract. As Pateman observes, '[w] hen contract and the individual hold full sway under the flag of civil freedom, women are left with no alternative but to (try to) become replicas of men' $(1988,187)$. Those women who are unable to do so will not succeed in their property claim. While the law provides redress for those who meet the requisite standard of exchange, it fails to acknowledge that the standard entrenches the male sex-right and in doing so upholds his claim to property by default.

Intimate partner trusts are the law's response to claims concerning shared spousal property. They adopt the existing individualistic framing of property rights, including the primacy of financial contribution and preferably a capital contribution. The law has been slow to recognise labour as sufficient to uphold a property right, and except in some contexts, ${ }^{81}$ continues to grapple with valuing non-financial contributions. So long as wives' labour is remitted pursuant to the sexual contract and not as individuals equal within the intimate union, the problem for women of the norms of individualism and its expression in market terms will remain.

Consequently, while the law might remain adequate on its own terms, those terms fail to give expression to women as individuals in their own right. This is so whether women are to be brought within the ambit of the propertied based on their free will and contribution independent of their status as wives, or whether acquiring property outside the realm of contract principles. As it stands however, the law's individualism is self-limiting.

First, the legal interest is given unquestioned priority. While this is self-evident based on the law's own terms, marriage is a common purpose again, according to the law's own construction. On this basis, the question might instead be asked as to whether spousal property distribution on an individualistic basis is, itself, just.

Secondly, and with reference to doctrine, the Australian courts' unconscionability approach is predicated on existing notions of the justification of private property. It does not extend to the conscience of the marriage relationship as a sexual contract. Instead, inbuilt into the notion of what is unconscionable is an inherent acceptance of the sexual contract. Further, unconscionability upholds property as an expression of individualism. On this basis, the courts

\footnotetext{
${ }^{81}$ Eg in Seguin v Vanasse, where the parties' contribution to the mutual endeavour was considered on equal terms. Reported in Kerr v Baranow [2011] 1 SCR 269.
} 
will find that failing to acknowledge a distribution of property proportionate to financial investment is unconscionable. By contrast, promising marriage to extract money and labour is not relevant. ${ }^{82}$ Nor for that matter are promises of sharing a home. ${ }^{83}$ The reason that they are not relevant lies in the currency of the sexual contract. The real question is whether such promises should be relevant to a claim for property.

Finally, and similarly, unjust enrichment fails to go to the heart of what is unjust about the parties' dealings. Indeed, male right to women's labour and her person might itself be branded 'unjust enrichment'. The law, however, measures the relevant contribution and consequential enrichment against market norms that render domestic enrichment invisible and just. So long as domestic labour holds no commercial value, it is not possible to ascertain the enrichment. To the extent that it might be understood as enriching, it is not unjust: it is a feature of male sex-right to demand and to receive the benefit of women's labour, her obedience for his protection.

Despite the success of many women in claiming property from their husbands, the effect of the law is inherently conservative, upholding men's property by default operation of the sexual contract. Such a tendency is at least in part explained by the place of women within marriage, and the terms of the exchange women enter into. On Pateman's reading, the exchange is concluded, transactionally, at the point of marriage after which the woman's labour sexual, emotional, physical, and reproductive - is a term of the contract (1988). By the time of considering property, wives have already expended their free will in entering the sexual contract, and their contributions are the quid pro quo for the exchange of obedience for protection - not for property. Both Pateman's analysis and the accompanying binary of emotions on the one hand and economic exchange on the other, deny 'material security to performances of domestic labour' (Silbaugh 2005, 338).

If the law operates this way to protect men's sex right attendant on the sexual contract, it might be asked why women are even given the possibility of challenging the legal estate. I suggest that despite appearances, the general law does not function to afford wives the right to spousal property per se. Rather, the general law functions to protect the property of men. Where the threshold is established as that of the man of the market engaged in immediate transactional exchange, the law will concede the woman's beneficial estate. But the default remains, courtesy of the sexual contract.

\section{References}

Arendt, Hannah. 1998. The human condition. Chicago: University of Chicago Press.

Australian Bureau of Statistics. 2009. Australian Social Trends Report 4102.0 https://www.ausstats.abs.gov.au/ausstats/subscriber.nsf/0/9B47C077B3B6C1AECA2575830015F 1CF/\$File/41020_ast_march2009.pdf. Accessed 16 July 2019.

Australian Human Rights Commission. 2009. Accumulating poverty? Women's experiences of inequality over the lifecycle. https://www.humanrights.gov.au/our-work/sexdiscrimination/publications/accumulating-poverty-womens-experiences-inequality-over. Accessed 16 July 2019.

Bankwest Curtin Economics Centre and Workplace Gender Equality Agency. 2018. Gender equity insights 2018: inside Australia's gender pay gap. https://bcec.edu.au/publications/gender-equity-insights-2018/. Accessed 16 July 2019

Burgoyne, Carole and Stefanie Sonnenberg, 'Financial Practices in Cohabiting Heterosexual Couples: A Perspectives from Economic Psychology' in Joanna Miles and Rebecca Probert (eds), Sharing Lives, Dividing Assets: An Inter-Disciplinary Study (Hart, 2009) 89

\footnotetext{
${ }^{82}$ Baumgartner v Baumgartner (1987) 164 CLR 137.

${ }^{83}$ Green v Green (1989) 17 NSWLR 343; Lloyd's Bank v Rosset [1991] 1 AC 107, 130.
} 
Bonthuys, Elsje. 2013. Equality and difference: fertile tensions or fatal contradictions for advancing the interests of disadvantaged women? In The Ashgate Research Companion to Feminist Legal Theory, ed. Margaret Davies and Vanessa E Munro 85-104. Oxford: Ashgate.

Elshtain, Jean Bethke. 1982. Introduction: toward a theory of the family. In The family in

political thought, ed. Jean Bethke Elshtain, 7-30. Amherst: University of Massachusetts Press.

Estin, Ann Laquer. 2005. Can families be efficient? A feminist appraisal. In Feminism Confronts Homo Economicus, ed. Martha Albertson Fineman and Terence Dougherty, 423- 449. London:Cornell University Press.

Fineman, Martha Albertson. 1995. The neutered mother, the sexual family. London: Routledge.

Flood, Jennifer. 2011. Share the wealth? Kerr v Baranow and the "joint family venture". Canadian Journal of Family Law 27 361-390

Galloway, Kate. 2015. Marriage and equality: what's love got to do with it? Alternative Law Journal 40(4): 225-228.

Graycar, Reg. 1992. Women's work: who cares? Sydney Law Review 14:86-105.

Graycar, Reg, and Jenny Morgan. 2004. Thinking about equality. UNSW Law Journal 27: 833-839.

Graycar, Reg, and Jenny Morgan. 2005. Feminist legal theory and understanding of equity: one step forward or two steps back. Thomas Jefferson Law Review 28: 399-422.

Graycar, Reg, and Jenny Morgan. 2010. Equality unmodified. In Sex discrimination in uncertain times, ed. Margaret Thornton, 175-196. Canberra: ANU E Press.

Hayward, Andrew, Judicial Discretion in Ownership Disputes over the Family Home (PhD Thesis, Durham University, 2013) <http://etheses.dur.ac.uk/8489/>

Hayward, Andrew. 2012. Family property and the process of "familialisation" of property law. Child and Family Law Quarterly 24:284-303.

Belinda et al. 2011. 'Men's engagement in shared care and domestic work in Australia' https://www.dss.gov.au/our-responsibilities/women/publications-articles/general/mensengagement-in-shared-care-and-domestic-work-in-australia. Accessed 16 July 2019.

Kessler, Laura T. 2005. Is there agency in dependency? Expanding the feminist justifications for restructuring wage work. In Feminism confronts homo economicus, ed. Martha Albertson Fineman and Terence Dougherty, 373-400. London: Cornell University Press.

Krouse, Richard W. 1982. 'Patriarchal liberalism and beyond: from John Stuart Mill to Harriet Taylor. In The family in political thought, ed. Jean Bethke Elshtain, 145-172. Amhers: University of Massachusetts Press.

Macneil, Ian R. 1974. The many futures of contracts. Southern California Law Review. 47:691-816.

Macneil, Ian R. 1981. Economic analysis of contractual relations: its shortfalls and the need for a 'rich classificatory apparatus'. Northwestern University Law Review 75:1018-1063.

Macneil, Ian R. 1986. Exchange revisited: individual utility and social solidarity. Ethics 96(3) 567-593.

Mayes, Elizabeth. 2005. Private property, the private subject, and women: can women truly be the owners of capital? In Feminism Confronts Homo Economicus, 117-130. London: Cornell University Press.

John Mee, 'Burns v Burns: The Villain of the Piece?' in R Probert, J Herring and S Gilmore (eds), Landmark Cases in Family Law (Hart Publishing, 2011) 175

Moody-Adams, Michele M. 1997. The social construction and reconstruction of care. In Sex, preference and family: essays on law and nature, ed. David M Estlund and Martha C Nussbaum, 3-16. Oxford: Oxford University Press.

Okin, Susan Moller. 1989. Justice, gender, and the family. New York: Basic Books.

Olsen, Frances E. 1983. The family and the market: a study of ideology and legal reform. The Harvard Law Review 96(7): 1497-1578.

Pateman, Carole. 1988. The Sexual Contract. Cambridge: Polity Press.

Pateman, Carole. 1989. The disorder of women. Cambridge: Polity Press.

Probert, Rebecca. 2007. Equality in the family home? Stack v Dowden. Feminist Legal Studies 15: 341-353

Rebecca Probert, 'Land, Law and Ex-Lovers' (2005) Mar/April Conveyancer and Property Lawyer 168;

Rebecca Probert, 'Trusts and the Modern Woman — Establishing an Interest in the Family Home' (2001) 13(3) Child and Family Law Quarterly 275;

Rotherham, Craig. 2002. Proprietary remedies in context. Oxford: Hart Publishing.

Sandel, Michael J. 1998. Liberalism and the limits of justice. Cambridge: Cambridge University Press. 
Sarmas, Lisa. 2012. Trusts, third parties and the family home: six years since Cummins and confusion still reigns. Melbourne University Law Review 36:216-249.

Shanley, Mary Lyndon. 2008. Justmarriage: on the public importance of private unions. In Marriage and cohabitation: regulating intimacy, affection and care, ed. Alison Diduck, 285-297. Oxford: Ashgate.

Silbaugh Katharine B. 2005. Commodification and women's household labor. In Feminism confronts homo economicus, ed. Martha Albertson Fineman and Terence Dougherty, 338-372. London: Cornell University Press.

Summers, Anne. 2016. Damned whores and god's police. Sydney: New South Books.

Thompson, Sharon, Lydia Hayes, Daniel Newman and Carole Pateman. 2018. The Sexual Contract 30 years on: a conversation with Carole Pateman. Feminist Legal Studies 26:93-104

Vogler, Carolyn, 'Managing Money in Intimate Relationships: Similarities and Differences between Cohabiting and Married Couples' in Joanna Miles and Rebecca Probert (eds), Sharing Lives, Dividing Assets: An Inter-Disciplinary Study (Hart, 2009) 61

Walzer, Michael. 1983. Spheres of Justice. Oxford: Martin Robertson \& Company.

Wong, Simone, 'Constructive Trusts over the Family Home: Lessons to Be Learned from Other Commonwealth Jurisdictions?' (1998) 18(3) Legal Studies 369

Wong, Simone, 'Trust(s) and Intention in Resolving Disputes over the Shared Home' (2005) 56 Northern Ireland Legal Quarterly 105

Wong, Simone, 'Would You “Care” to Share Your Home?' (2007) 58 Northern Ireland Legal Quarterly 268

Wong, Simone, 'Shared Commitment, Interdependency and Property Relations: A Socio-Legal Project for Cohabitation' (2012) 24 Child and Family Law Quarterly 60

Yodanis, Carrie and Sean Lauer. 2014. Is marriage individualized? What couples actually do. Journal of Family Theory \& Review 6(2):184-197. 